UDC 811.111

DOI https://doi.org/10.32841/2409-1154.2020.45-2.21

\author{
Lazebna N. V., \\ Ph.D. in Philology, \\ Assistant Professor at the Department of Theory and Practice of Translation \\ "Zaporizhzhia Polytechnic" National University
}

\title{
PARAMETERS OF ENGLISH-LANGUAGE INNOVATIVE TECH DISCOURSE
}

Summary. The modern world is developing at a full pace. A number of innovative sciences and technologies emerge at the intersection of various industries. Robotics, nanotechnology, biotechnology and related novice fields require the study of their lexical content, textual representation and discursive studies. Integrated lexical markers in the studied type of discourse are combined into a harmonious textual unity, which, penetrating into all spheres of this discourse dwellers' lives, requires linguistic concern and pragmatic focus. Currently developing fields of science, which have rich interdisciplinary links and are characterized by the complexity of terminology, a wide range of lexical and stylistic means are used to create a certain universal linguistic phenomenon. Globalization of the world and human /machine interaction are two powerful triggers, which are changing social mode of the contemporaries and their lives, and, at the same time coining innovative lexical units, project them onto a novice technological and informational background.

Being on the verge of technology and society, English language goes global and represents a universal verbal continuum with no set boundaries restricting terms and common vocabulary. Relevance of this study can be correlated with the development of innovative industries and the need for communication of professionals engaged. Focus on linguistic and pragmatic features of the discourse shall contribute to the effective perception of related texts, terminological units thus determining recipients' adequate comprehension of the information obtained. This paper outlines further analysis of English-language innovative discourse mediated by technologies, represented in multimodal context and embodied by a wide range of both verbal and non-verbal means.

Key words: innovative tech discourse, terminological units, anthropocentric paradigm, linguistic means, robotics, human and machine interaction, verbalization.

Scientific disciplines are entities that have a life cycle: they are born, they grow, they interconnect with other disciplines, they enter into family like relationships, they divorce, they give birth to other disciplines, and they wither and may subsequently die.

Kastberg

Introduction. Human progress has often correlated with technological, scientific and informational advancement. Reflected in innovative English-language terminology, which mediates communication between the scientists and researchers, this refined linguistic phenomenon requires a comprehensible study. According to researchers in the field of digital linguistics, contextual representation of verbalized knowledge within innovative technologies and other related areas represents a merge of verbal/ nonverbal means. Therefore, versatile modes of communication in modern scientific and technical context spread within multimodal space. This new social and linguistic phenomenon, Englishlanguage innovative tech discourse, blurs the limits between humans and machines and creates the socio-verbal foreground that mediates communication of modern society. Relevance of this study can be correlated with the development of innovative industries and the need for communication of professionals engaged.

Literature review. Despite many attempts to determine English-language digital or computer discourse, there is still no single definition and parameters acting therein. Based on classical works in this area of study, we will further correlate the principles of discourse development $[5 ; 8 ; 9 ; 12]$.

Being in the center of modern anthropocentric linguistic paradigm, a human being uses language to convey his ideas, bridge the communicative gap between the speakers, and, from this perspective, English language goes global and furthers humans in their aspirations. Human mind and emotions are an inseparable shell reflecting acquired knowledge. Thus, emotiveness and figurative components of innovative terms represent an integrative component of modern English discourse. Despite profound studies of imagery, metaphors, and expressiveness, the relationship of these categories within scientific and technical space have often been underestimated.

Robotics stands in close relationship with chemistry, biology, medicine, engineering and other classical sciences. Purpose of this study is to determine the linguistic and pragmatic features of innovative tech discourse. This research will contribute to the adequate perception of related texts, terminological units thus determining recipients' adequate comprehension of the information obtained.

Results and discussion. In modern linguistics, the definition of discourse was given by Z. Harris, I. S. Shevchenko and other researchers have been considering and theorizing a lingual and social phenomenon of discourse. Focusing on the global integration and a total merge of innovative sciences and their further extrapolation within the global community, there is a great need for reconsideration of this phenomenon. Modern textual space has already crossed the barriers of the specifically scientific community [7, p. 151]. It is being popularized and promoting new technologies in the global world.

Interdisciplinarity is a link, connecting different fields of science. The empirical material has been collected in English-language text corpora (iWeb : The 14 Billion Word Web Corpus, Science Blogs), online academic journal articles and monographs. A natural flow of English-language scientific and technical discourse integrates both specific expressions and common words, reflecting historical, social and cultural conditions. Thus, texts in robotics in their content and structure reflect the temporal aspect, interaction between the author and recipients, and the space of its development. 
For example, in the journal article, the author conveys the ideas about the frontiers of robotics in a comprehensible manner:

Robot-assisted surgery operations are being performed more frequently in the world these years. In order to have a macroscopic view of publication activities about robotic surgery, the first bibliometric analysis was conducted to investigate the publication distributions of robotic surgery.

Top-ranking academic publisher popularizes robotics technology in medicine thus expanding the potential customers and spreading the ideas found in scientific explorations. The global context of robotics discourse focuses on the dialogue of communicators, specific technical knowledge, and common linguistic/ extralinguistic focus of the audience.

Nevertheless, ambiguities may occur and hamper communication in the context of innovative technologies. Different communicative strategies can be applied across various areas of robotics, biotechnology, nanotechnology and other related fields. There is often a lack of emotional charge, synonyms and terminological units, which cannot be understood beyond this context. Fortunately, the absolute predominance of cognitive information in the English-language discourse of innovative technologies determines the logical rather than the associativefigurative way of its development.

Consider fig. 1, which depicts a certain relationship between robotics and related technologies. Actually, there is a number of other fields, which can be added to this diagram and it would go far beyond the frame represented. There is a cycle of interdependencies, which occur in one or another subfield of robotics. Interdisciplinarity of considered areas and linguistic means implemented therein, are of key concern for the study.

English-language integrative potential absorbs specific features and linguistic tools used by a variety of novice technologies. According to texts considered, innovative discourse of modern English language is developing according to the following points:

1) real process of communication, where the researcher represents all textual and extralinguistic parameters;

2) creation and interpretation of the text created via online community;

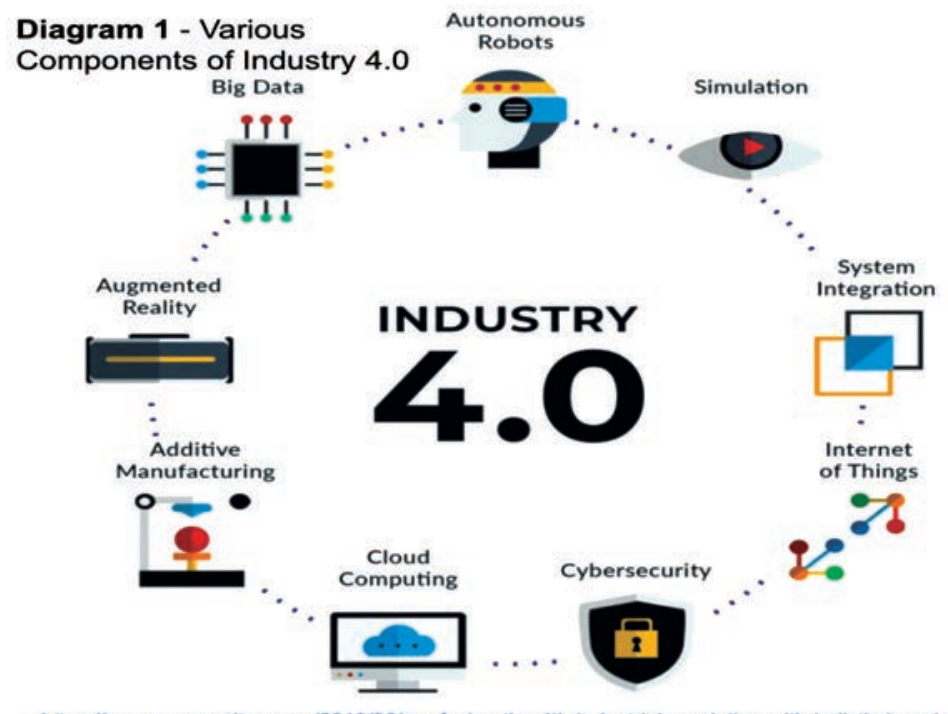

https://mww.mum-writes.com/2018/06/rex-facing-the-4th-industrial-revolution-with-holistic-learning

Fig. 1. Industry 4.0 Interdisciplinarity of components
3) variation of textual characteristics, strategies and tactics of communication under the influence of extralinguistic factors.

The major reason for the dynamic properties of Englishlanguage innovative technologies discourse can be found in the social links between the texts and life of the global society. According to modern technologies developers:

The promises of today's emerging technologies include longer, healthier lives; safer, faster, and more efficient transportation; and immediate, far-reaching communication mechanisms. Rapid technological innovation often outpaces and challenges established legal regulations, cultural norms, and societal frameworks of communications [1].

Thus, discourse of innovative technologies goes far beyond language and communicative situation. Led by the statements of T. van Dijk and W. Kinch, it is possible to outline specific strategies inherent in the English-language discourse of innovative technologies [10, p. 18]. Discursive strategies, in their view, are largely similar to grammatical strategies. Newly created sentences depend on the information contained in the texts. At the same time, the basis of semantic and pragmatic interpretation of discourse is information isolated from sentences. Grammatical and discursive strategies are interdependent. However, the researchers highlight special strategies specific only to discourse, such as cultural, social, semantic, structural, stylistic and rhetorical ones. Anthropocentric orientation of texts in the field of innovative technologies and their focus on the global community are reflected in various semantic and stylistic means [2, p. 230].

Based on the example of the Moon exploration research, we can see that robots and humans are both compared and contrasted: Most concepts for Moon/Mars exploration envision a mix of robots and humans. However, the criteria for deciding how each of them should be used, and in what combination, are not usually stated and probably were never formally developed. The result is that the concepts are biased according to the background of the study group; human exploration advocates tend to minimize the use of robots, whereas traditional space scientists tend to downplay the potential of human presence [11].

Highlighted phrases indicate a gradual dominance of robots and their role in Moon exploration. On the one hand, it means a universal technical role of robots, which can further undermine the role of humans in the scientific and technological development. On the other hand, such interaction was initially established by humans to foster technological progress in different spheres of life.

The purpose of this discourse type is the process of representing new knowledge on the subject, phenomenon, its properties and qualities. Thus, logic of narration cannot be discarded and logic of information too. Beyond the dominant function of intellectual and communicative informing, we can see a big discursive space in the field of robotics, which integrates related classical fields of science, such as physics, chemistry, mathematics, and this innovative technical and scientific textual space becomes more attractive for the wide audience.

Socially-friendly English-language discourse of innovative technologies is still finding its key point. Maybe, robots will guide its further development, because they are currently in 


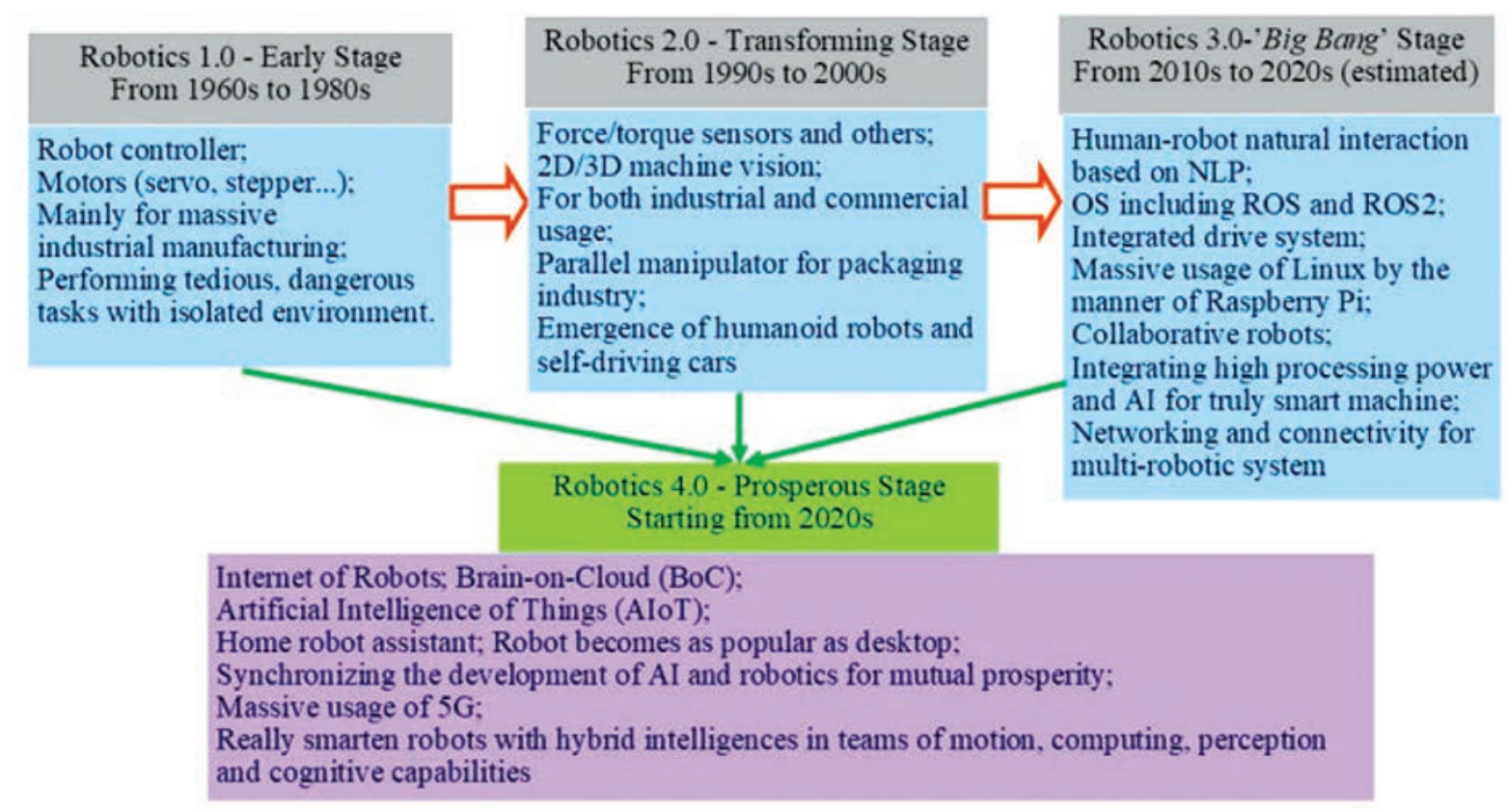

Fig. 2. Robotics development (iWeb image)

the forefront of integrated fields and studies. English-language discourse of innovative technologies can be referred to as one universal definition. This is an oral or written process and the result of interaction between participants in communication mediated by new technologies or thematically related texts. This type of discourse is characterized by a specific social and cultural situation of communication, cognitive and linguistic competencies of the participants involved therein.

In terms of scientific discoveries, it is evident that interdisciplinarity is an interaction of two or more scientific disciplines, with their own subject, terminology and research methods. The concept of interdisciplinarity requires the deconstruction of various integrated meanings [4]. Robotics as an integral research field, bringing closer humans and machines, implies interaction of various factors and interdependence of features.

We can compare this expansion with a deeper human delving into depths of science. Thus, broadening human cognition in terms of this field is another point to consider. Actually, interdisciplinarity should be considered as an immanent feature of cognition. Focusing on general concepts found in the context of robotics, one can trace general lexical markers, which outline interdisciplinarity of the field.

Table of lexical markers summarized from texts corpora iWeb in the field of robotics reflect typical terms of physics, biology, mathematics, and different innovative technologies. These terminological units are integrated into the English discourse of innovative technologies erasing the boundaries of their origin and forming a new universal termbasis. The process of reterminologization implies transfer of one term from one field into another with its full or partial modification and transformation into an interdisciplinary homonym. There is a complicated path of terms transcedence from one field into another; thus, terms are migrating and changing their meaning [3, p. 592].

The interaction of the discourse components determines discourse as an integral object representing processes of human
Table 1

Lexical markers of interdisciplinarity
\begin{tabular}{|c|c|c|}
\hline$\#$ & Term & Field of origin of the term \\
\hline 1 & algorithm & mathematics, innovative technologies, robotics \\
\hline 2 & bacteria & biology, microbiology, nanotechnology \\
\hline 3 & computer display & $\begin{array}{c}\text { innovative technologies, microelectronics, } \\
\text { nanotechnologies }\end{array}$ \\
\hline 4 & conductor & physics, electrical engineering, mathematics \\
\hline 5 & electrical current & physics, electrical engineering, nanotechnology \\
\hline 6 & grid & $\begin{array}{c}\text { innovative technologies, biology, electrical } \\
\text { engineering, biotechnology, robotics }\end{array}$ \\
\hline 7 & microelectronic circuit & innovative technologies, nanotechnologies \\
\hline 8 & nanometer & nanotechnology, microelectronics \\
\hline 9 & optical microscope & nanotechnology, telecommunications \\
\hline 10 & torque & physics, mathematics \\
\hline
\end{tabular}

cognition development. Cognitive, social, cultural and linguistic features are combined and reflected in the discourse of innovative technologies. Cognitive perspective allows us to consider discourse as a fragment of knowledge in a particular subject area; social view represents it as a fragment of social space, and cultural lenses highlight discourse as a fragment of culture based on the cultural values of a particular ethnic group.

Having said that the laws of science are themselves cultural artefacts we can now take a critical look at the generally accepted idea that technical disciplines should be cultureless. The reasoning behind such an idea can probably be reconstructed along the lines of a syllogism much like this one: Physical theories are acultural / Technical disciplines stem from physical theories/ Therefore technical disciplines are acultural [6, p. 104].

There is a unified narrative of robotics or other innovative technologies, which broadening their horizons and are being popularized lately.

Like networks, humans too are seen as informational, multiple and fragmented. Networks allow for a better commensurability 
and deeper interaction between humans and technology. Through the integration of humans and technology, and the construction of the cyborg, the engagement of humans with the world becomes more meaningful and allows greater degrees of freedom [2]

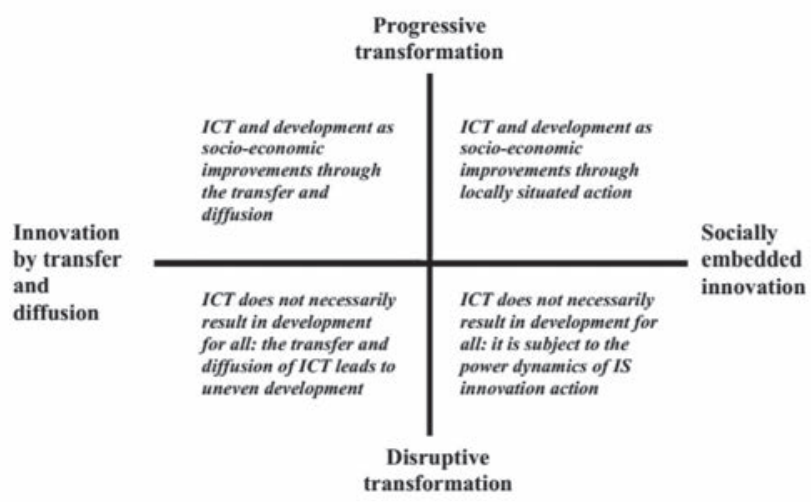

We may refer to this correlation of technologies development and expansion, and focus on quadrant of tech discourse, if it is possible to name it like that. The first stage of innovation by transfer and diffusion can be compared with the development of a terminological unit. The second stage of socially embedded innovation refers to social absorption of a new or reterminologized lexical unit or expression. From progressive to disruptive transformation, one can consider a split nature of a dominant lexical unit, or an innovative term within innovative tech discourse.

Conclusions. English discourse of innovative technologies demonstrates inherent characteristics such as logical, sequential and linked presentation of information. There is no need to use complicated syntax structures, rather, it is relevant to popularize this type of discourse to make it more open and welcoming for the global audience. This popularization is reached through a variety of English techniques, including lexical and syntactic means.

Functional and semantic analysis shows that linking words, juxtaposition, and other cohesion means are used to reach texts coherence. From the functional perspective, the English-language discourse of innovative technologies is informative, open, popularized, and, at the same time, cohesive and coherent. Nonverbal means in the texts of robotics are represented by a large variety of sign systems, symbols, diagrams, tables and drawings. Perspective of the study can be found in discussion of pragmatics, communicative strategies and specific communicative blocks within the discourse studied.

\section{References:}

1. Engineering \& Applied Science (EAS). URL: https://catalog.upenn. edu/courses/eas/ (accessed December 15, 2020).

2. Fisher E. Contemporary Technology Discourse and the Legitimation of Capitalism. European Journal of Social Theory. Vol. 13(2). P. 229-252.

3. Gao Z. From Industry 4.0 to Robotics 4.0 - A Conceptual Framework for Collaborative and Intelligent Robotic Systems. Procedia Manufacturing. 2020. No. 46. P. 591-599.

4. Global scientific production of robotic surgery in medicine: A 20-year survey of research activities / Fan G., Zhou Z., Zhang H. [et al.]. International Journal of Surgery. Vol. 30. 2016. URL: http://www.sciencedirect.com/science/article/pii/ S1743919116300796 (accessed December 15, 2020).
5. Harris Z. Discourse Analysis. Language. 1952. P. 1-30.

6. Kastberg P. Cultural Issues Facing the Technical Translator. The Journal of Specialised Translation. No. 8. 2007. P. 104-109.

7. Lipschultz J.H. Free Expression in the Age of the Internet Social and Legal Boundaries. Boulder, CO : Westview Press, 2000. 331 p.

8. Matheson D. Media Discourses: Analysing Media Texts. Maidenhead, England : Open University Press, 2005. 206 p.

9. Prykhodko A.M. Discourse acts: pragmasemantics and pragmatypology. Cognition, Communication, Discourse. 2018. No. 1. URL: https://doi.org/10.26565/10.26565/2218-2926-2010-0107 (accessed December 15, 2020).

10. Rich C., Sidner C.L., Lesh N. Collagen: Applying Collaborative Discourse Theory to Human-computer Interaction. AI Magazine. 2001. Vol. 22. No. 4. P. 15-26.

11. Robots and humans: an integrated approach. National Research Council. Scientific Opportunities in the Human Exploration of Space. Washington, DC : The National Academies Press. 1994. 48 p.

12. Shevchenko I.S. Diskurs kak kognitivno-kommunikativnyj fenomen: edinicy i kategorii [Discourse as cognitive-communicative phenomenon: units and categories]. Linguistic studies : a collection of articles of Yerevan State Univ. Erevan : Limush Publ. 2015. No. 5. P. 146-158 [in Russian].

Лазебна Н. В. Параметри англомовного дискурсу інноваційних технологій

Анотація. Сучасний світ розвивається швидкими темпами. Безліч інноваційних наук і технологій виникає на стику різних галузей. Робототехніка, нанотехнології, біотехнології та суміжні інноваційні галузі потребують вивчення їхнього лексичного змісту, аналізу тексту та дискурсивних досліджень. Інтегровані лексичні маркери в досліджуваному типі дискурсу поєднуються в гармонійну текстову єдність, яка проникає у всі сфери життя людини. У цій площині відбувається реінвентаризація термінологічного апарату, зміна комінікативних стратегій і тактик, що і коригує певною мірою лінгвістичний фокус досліджень згідно із розвитком міждисциплінарних зв'язків. Нині галузі науки, що розвиваються і мають міждисциплінарні зв'язки, характеризуються складністю термінології, а широкий спектр лексичних та стилістичних засобів створює певне універсальне мовне явище. Глобалізація світу та взаємодія між людиною та машиною є двома потужними механізмами, які змінюють соціальний устрій сучасників та їхнє життя і одночасно створюють інноваційні лексичні одиниці, проєктують їх на технологічну та інформаційну площину.

Перебуваючи на межі технологій та суспільства, англійська мова стає глобальною і являє собою універсальний словесний континуум без жодних обмежень, що можуть бути певною рестрикцією термінології та загального словникового запасу. Актуальність цього дослідження може бути пов'язана з розвитком інноваційних галузей та необхідністю спілкування професіоналів, а також розширенням меж цільової аудиторії. Зосередження уваги на мовних та прагматичних особливостях дискурсу уможливить ефективне сприйняття споріднених текстів, термінологічних одиниць, що і визначатиме адекватне розуміння одержувачем інформації. У цій роботі пропонується подальший аналіз англомовного інноваційного дискурсу, опосередкованого технологіями, представленими в мультимодальному контексті та втіленими широким спектром як вербальних, так і невербальних засобів.

Ключові слова: інноваційний технічний дискурс, термінологічні одиниці, антропоцентрична парадигма, лінгвістичні засоби, робототехніка, взаємодія людини та машини, вербалізація. 